\title{
Strategies for Increasing the Role of Ports in Supporting the Development of Makassar City
}

\author{
Rini $^{1}$, Budimawan², Ganding Sitepu ${ }^{3}$ \\ ${ }^{1}$ Regional Development Planning Program for the Postgraduateof Hasanuddin University \\ ${ }^{2}$ Faculty of Marine Science and Fisheries, Hasanuddin University \\ ${ }^{3}$ Faculty of Engineering, Hasanuddin University \\ Email: rini.su.rs@gmail.com ${ }^{1}$, budimawan@yahoo.com² ${ }^{2}$,g.sitepu@ $@$ unhas.ac.id ${ }^{3}$
}

\section{ABSTRACT}

Ports as marine transportation infrastructure have a very important role for the national and regional economies as well as relations between regions and between countries. Ports can play a role in stimulating the growth of economic, trade, and industrial activities from their areas of influence. To increase this role, of course, it must be supported by good performance. This study aims to (1) analyze the influence of Makassar Port in supporting the development of Makassar City and analyze the operational performance of Makassar port; and (2) Formulating a strategy to increase the role of ports in supporting the development of Makassar City. This research uses quantitative descriptive analysis method for GRDP data and port performance, simple linear correlation, and regression analysis are used to show the relationship and influence of goods traffic flow with GRDP of Makassar City, and field force analysis is used to determine strategies for increasing the role of ports. The results show that the Makassar Port has a significant effect in supporting the development of Makassar City and the performance of the Makassar Port during the last five (5) years has performed well. The strategic priorities for increasing the role of Makassar Port in supporting the development of Makassar City are the development of the Makassar New Port (MNP) terminal and dredging the port pool.

Keywords:Port Performance; GRDP; Field Force Analysis, Strategy

Article Received: 18 October 2020, Revised: 3 November 2020, Accepted: 24 December 2020

\section{Introduction}

Sea transportation is one of the transportation subsectors that provides a very large contribution to the national and regional economies as well as relations between regions and between countries. Sea transportation is still the main choice because of its high economic value, relatively low cost, and large carrying capacity. The port is a vital sea transportation node.

Makassar City is located in a strategic position because it is at the intersection of traffic lanes from the south and north in the Sulawesi province, from the western region to the eastern region of Indonesia, and from the north to the southern region of Indonesia. This condition provides an opportunity for the City of Makassar to grow and develop not only as a gateway but positioned as a living room in Eastern Indonesia.

The GRDP of Makassar City as an indicator of regional development has increased from year to year and is the city that has the highest GRDP in South Sulawesi Province according to data from the Central Statistics Agency. This shows the magnitude of economic activity in Makassar City. The development of Makassar City occurs in various sectors such as industry, trade, services, construction, and others. The development of various sectors in Makassar City cannot be separated from the role of the port as a distribution service node and a gateway for the flow of goods and services both between regions, provinces and between countries.

Makassar Port is one of the gateway ports in Indonesia. As a gateway port, the Port of Makassar 
serves interstate, inter-provincial trade as well as being a collector and distributor of goods to Eastern Indonesia due to its strategic location and support from the hinterland area of South Sulawesi. The distribution of goods and services at the Port of Makassar has increased every year. Each year, the export and import activities as well as the distribution of goods and services in the Makassar Port will have an impact on the decline in port operational performance if it is not followed by improvements in facilities and infrastructure and limited areas for port development. The declining port operational performance condition of course will affect the distribution of goods and services between regions which in turn will have an impact on the less than the optimal role of the port as a support for the development of Makassar City.

Based on the description above, it is deemed necessary to research to formulate a strategy to increase the role of the Makassar port in supporting the regional development of Makassar City.

\section{LITERATURE REVIEW 1. Port}

Port includes transportation infrastructure and system, namely a work environment consisting of land and water areas equipped with facilities for anchoring and mooring of ships, to carry out loading and unloading of goods as well as the ups and downs of passengers from a sea transportation mode (ship). ) to other modes of transportation or vice versa ((Triatmodjo, 2010: Jinca, 2011; Suranto in Putra \&Djalante, 2016).

Ports have a strategic role to support the transportation system because they become a point of connection between regions/countries. Ports are also a place of intra and Intermodal transportation (Oblak, Bistricic, \&Jugovic, 2013)

According to Berkoz\&Tekba in (Putra \&Djalante, 2016), socially a port becomes a public facility where interactions between users (the community) take place, including interactions that occur due to economic activity. socially and economically, ports are also important from the political side. That is, with its strategic role as a center of interaction that has economic value and the lifeblood of a nation's socio-cultural dynamics, ports have very strategic political values to maintain and maintain their existence and sovereignty.

Port performance is the output of the success rate of service/use of port equipment facilities. in a certain period (time) which is determined in terms of units of time, unit weight, ratio (percentage), or other units. Port performance can be used to determine the level of port service depending

on the service time of the ship while at the port (Triatmodjo, 2010). According to Talley in (Putra \&Djalante, 2016), effectiveness is related to how well the port provides services for the flow of goods to users of shipping and shipping companies.

Port operational service performance is carried out by measuring all port activities to obtain a service product measure, namely port operational performance, which includes service aspects, productivity aspects, and port utility aspects.

2. Regional Development

According to Friedman \&Allonsoin (Dewi, Purwanto, \&Sapei, 2014), regional development is strongly influenced by certain components such as local resources, markets, labor, investment, government capacity, transportation, and communication and technology.

In regional development, there are three fundamental elements, namely the existence of a center, area of influence or service area, and the availability of transportation networks (Adisasmita, 2011). The connection between regions is defined as the existence of a connection between two or more regions, usually indicating a two-way or reciprocal relationship between one region and another. 
The essential characteristic or characteristic of a city is the concentration of the economic, social, and political activities of the population in spatial planning (Adisasmita, 2018). Economic activity is often the basis for the development of a city.

According to (Syam, 2013) theoretically, the growth of an area is determined by economic growth opportunities and responses to take advantage of these economic opportunities. Growth indicators of a region such as GRDP / per capita, a growth rate of leading sectors, the contribution of leading sectors to GRDP, government investment, population, growth in the number of companies, and development plans for government and private projects.

3. The Role of Ports in Regional Development

According to Bryan et al in (Mandasari, Kusumastanto, \&Mulyati, 2017), the role of ports in economic development is getting bigger along with the increasing importance of ports in logistics activities, especially intermodal or multimodal transportation.

According to Richardson and Heidelberg in (Mandasari et al., 2017), ports can support the local and national economy, encourage industrial development, provide employment both directly and indirectly to residents and generate income for local governments.

According to Damapolii in (Putra \&Djalante, 2016), the region will develop if there are interinsular trade activities from the region to other regions, resulting in an increase in development investment and an increase in economic and trade activities. Revenue derived from exports will result in the development activities of the local population, transfer of capital and labor, external profits, and further regional development.

Distribution services (tertiary sector) have an important role and a major contribution to the global economy and trade (Adisasmita, 2011). The calculation of GRDP has become a very important part of macroeconomics, especially regarding the economic analysis of a region. The results of this GRDP calculation provide a basic framework used to measure economic activities that occur and take place in economic activity. The GRDP figures serve as macroeconomic indicators and also serve as a basis for evaluating economic performance and formulating various policies. This economic indicator also provides an overview of the flow of all value-added goods and services produced and all production factors used by the economy to produce added value for goods and services (Rakhman, Neneng, Saputri, \&Fisu, 2020).

\section{RESEARCH METHOD}

This research is a descriptive study with quantitative and qualitative approaches. The quantitative approach is carried out through the process of analyzing loading and unloading data at the Makassar Port which is linked to the Makassar City GRDP data, per capita income, and analysis of Makassar Port performance data. The qualitative approach to this research is the analysis carried out to describe the driving and inhibiting factors of port performance and in developing a strategy to increase the role of ports.

The data used in this study are primary data and secondary data. Primary data collection is obtained through observation and direct interviews in the field. Meanwhile, secondary data collection is obtained through documentation from various information or related agencies related to the scope of research.

The data analysis technique is carried out through quantitative descriptive analysis for GRDP data and port performance, correlation analysis, and simple linear regression are used to show the relationship and influence of goods traffic flow with the GRDP of Makassar City, and force field analysis is used to determine the port role enhancement strategy.

\section{RESULTS AND DISCUSSION}




\section{Regional Overview}

1. Makassar City

The City is the capital city of South Sulawesi Province, located on the West Coast of Sulawesi Island at the coordinates $119^{\circ} 18^{\prime} 27.79$ "$119^{\circ} 32^{\prime} 31.03$ 'East Longitude and $05^{\circ} 03 ' 30,81$ "$05^{\circ} 14^{\prime} 06.49$ " south latitude. Makassar City area is recorded as $175.77 \mathrm{~km}^{2}$. Administratively, Makassar City is divided into 15 Districts and 153 Kelurahan. Urban spatial structure plan includes plans city service center system and urban area infrastructure network system plan.

Based on the RTRW of Makassar City, it is stated that there is an Integrated Port Area to be built in Makassar City. The Integrated Port Area is an area directed as an area that provides strong support in one spatial system that synergizes various complete interests and activities related to port activities and all its requirements The Integrated Port Area is located in the central west and north of the city, covering the Ujung Tanah and Wajo Districts, as shown in Figure 1.
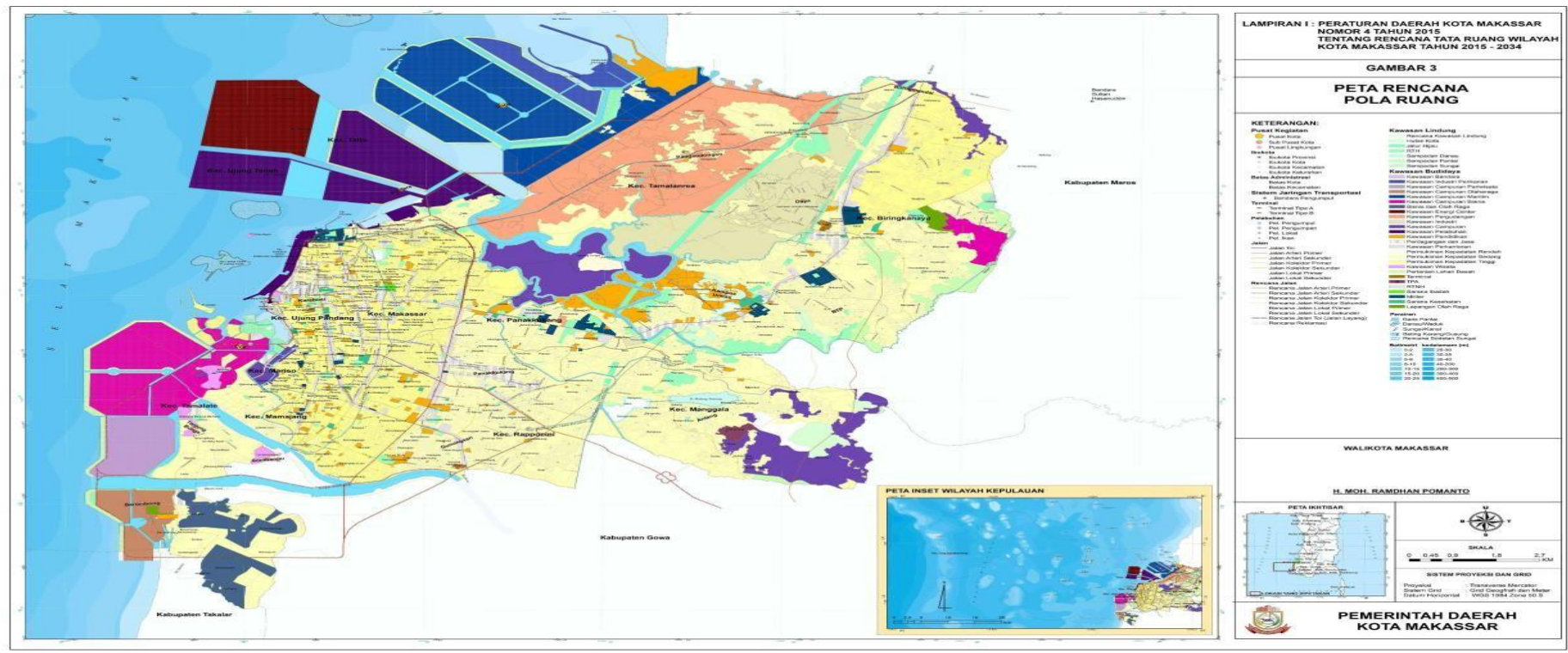

Source: Article Number 4 of 2015 About RTRW Makassar City 2015-2034

Figure 1. Map of Makassar City Space Pattern Plan

Economic growth is one of the macro indicators to see economic performance in an area. The size of the role of various economic business fields in producing goods and services greatly determines the economic structure of a region. Based on data from BPS Makassar City, during the last five years (2015-2019) the economic structure of Makassar City has been dominated by 3 (three) categories of business fields, including Manufacturing Industry; Wholesale and Retail
Trade, Car and Motorcycle Repair; and Construction. These three categories contributed $56.99 \%$ to the total GRDP of Makassar City. The increase in the PDRB of Makassar City was caused by the increase in the production of goods and services in almost all categories of business fields that experienced positive growth even though there were 2 (two) sectors that experienced negative growth, namely the Mining and Excavation business fields and the Water Supply, Waste Management, Waste, and Recycling business fields. 
Table 1. GRDP at Current Market Prices by Industry in Makassar Municipality (Million Rupiahs) 2011-2019 $\begin{array}{llllll}\text { No. } & \text { Industry } & 2015 & 2016 & 2017 & 2018\end{array}$

\begin{tabular}{lrrrrr}
\hline 1. Agriculture, Forestry and & $663.715,90$ & $745.145,33$ & $793.150,09$ & $808.428,97$ & 854.968 \\
Fishing & & & & & \\
2. Mining and Quarrying & $1.591,97$ & $1.417,68$ & $1.242,47$ & $1.102,08$ & 991 \\
3. Manufacturing & $23.133 .802,9$ & $26.407 .775,9$ & $28.422 .310,0$ & $29.380 .566,3$ & 32.666 .060 \\
& 7 & 5 & 6 & 9 & \\
4. Electricity and Gas & $32.518,97$ & $36.489,63$ & $43.855,71$ & $50.468,56$ & 54.824 \\
5. Water Supply, Sewerage, & $252.232,59$ & $263.059,54$ & $284.373,45$ & $307.684,75$ & 306.466 \\
$\quad \begin{array}{l}\text { Waste Management and } \\
\text { Remediation Activities }\end{array}$ & & & & &
\end{tabular}

6. Construction

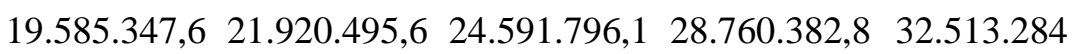

$5 \quad 6 \quad 2$

7. Wholesale and Retail

$20.909 .471,4 \quad 23.899 .356,127.216 .388,99 \quad 31.753 .861,0 \quad 36.513 .391$

Trade, Repair of Motor

$7 \quad 3$

Vehicles and Motorcycles

8. Transportation and $\quad 2.969 .115,92 \quad 3.273 .811,52 \quad 3.684 .140,21 \quad 4.151 .019,78 \quad 4.588 .975$ Storage

9. Accomodation and Food $\quad 2.671 .179,86 \quad 2.878 .592,72 \quad 3.224 .066,53 \quad 3.698 .770,59 \quad 3.980 .369$ Service Activities

10. Information and
$\begin{array}{lllll}10.199 .799,6 & 11.447 .604,3 & 12.848 .060,8 & 14.801 .742,9 & 16.204 .129\end{array}$
$\begin{array}{llll}6 & 9 & 2 & 1\end{array}$ Communication

11. Finansial and Insurance

$\begin{array}{lllll}6.834 .525,02 & 7.949 .618,40 & 8.823 .367,69 & 9.706 .799,51 & 10.375 .078\end{array}$ Activities

12. Real Estate Activities

4.944.278,20 5.308.899,90 5.569.654,13 5.957.040,88

6.378 .524

13. Jasa Perusahaan

$\begin{array}{lllll}1.359 .868,05 & 1.490 .583,58 & 1.660 .863,96 & 1.897 .195,13 & 2.163 .559\end{array}$

14. Public Administration and

$\begin{array}{lllll}4.221 .822,92 & 4.309 .671,16 & 4.683 .232,41 & 5.494 .161,12 & 6.090 .926\end{array}$ defence, Compulsory

Social Security

15. Education

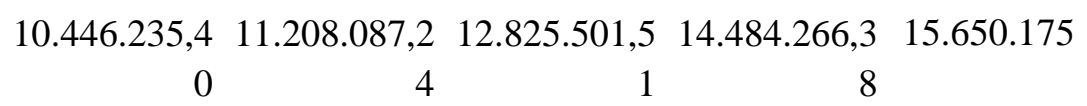

16. Human Health and Social $\quad 3.092 .320,38 \quad 3.502 .580,47 \quad 3.967 .270,02 \quad 4.483 .768,91 \quad 5.020 .835$ Work Activities

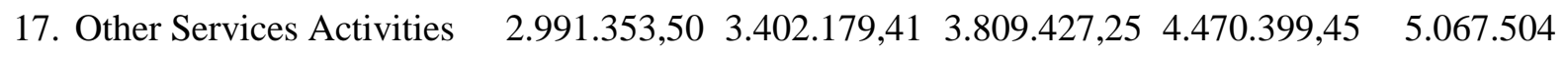




\begin{tabular}{lrrrrrr} 
No. & Industry & 2015 & 2016 & 2017 & 2018 & 2019 \\
\hline \multirow{2}{*}{ GRDP } & $\mathbf{1 1 4 . 4 3 2 . 1 3 0}$, & 128.045 .368$, & 142.448 .701$, & 160.207 .659$, & 178.430 .05 \\
& 44 & 71 & 43 & 28 & 7,22
\end{tabular}

Source :BPS Makassar City 2020

2. Makassar Port

Port is located in the administrative area of Makassar city, South Sulawesi Province with a long shape from the north coast to the west coast of Makassar city, crossing four sub-districts, namely Tallo District, Ujung Tanah District, Wajo District, and Ujung Pandang District.

Makassar Port already has a Port Master Plan which is stated in the Decree of the Minister of Transportation Number PM 92 of 2013 as amended by the Decree of the Minister of Transportation Number KM 48 of 2020 concerning the Makassar Port Master Plan. DLKr and DLKp Makassar Port have been determined based on the Decree of the Minister of Transportation Number KM 215 of 2019 concerning the Boundaries of the Work Environment Area and the Interests of the Makassar Port, with an area of land Work Environment (DLKr) covering an area of $94.72 \mathrm{Ha}$, Working Environment Area (DLKr) ) waters covering an area of 9,270 $\mathrm{Ha}$, and an Area of Interest (DLKp) covering an area of 12,505 Ha.

Based on the Decree of the Minister of Transportation Number KP 432 of 2017 concerning the National Port Master Plan, Makassar Port is designated as the Main Port with Makassar New Port Container Terminal and Paotere Terminal as Public Terminal. The existing terminals are Soekarno Terminal, Hatta Terminal, and Hasanuddin Terminal. The terminal is located at the following geographic coordinates:

Hatta Terminal: $05^{\circ} 07^{\prime} 46,98^{\prime \prime}$ SL $119^{\circ} 24^{\prime} 15,38^{\prime \prime}$ EL

Hasanuddin Terminal: $05^{\circ} 07^{\prime} 35,25^{\prime \prime}$ SL $119^{\circ} 24^{\prime}$ 27,85" EL

Terminal Soekarno: 05 07' 14,29" SL 119²4' 29,19 "EL

Paotere Terminal: $05^{\circ} 06^{\prime} 34,22^{\prime \prime}$ SL $119^{\circ} 25^{\prime}$ 17,80" EL

Terminal Makassar New Port : $05^{\circ} 05^{\prime} 44,17^{\prime \prime}$ SL $119^{\circ} 24^{\prime} 57,73^{\prime \prime} \mathrm{EL}$

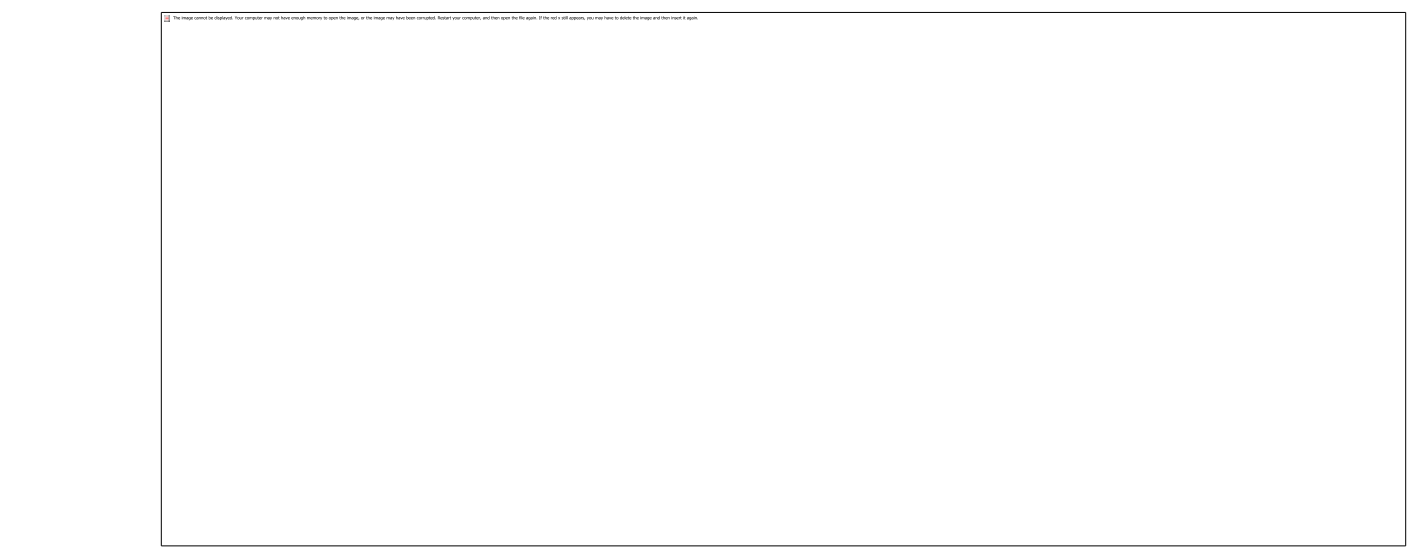

Source : KM 48 of 2020

Figure 2. Makassar Port Existing

Makassar Port Operations include the flow of ship visits both domestic and foreign, domestic and foreign goods traffic, as well as passenger flows. Data on the flow of domestic and foreign goods 
traffic at the Port of Makassar for the 2011-2019

period can be seen in Table 2 .

Table 2. The Flow of Domestic Goods and Foreign Affairs in Makassar Port 2011 - 2019

\begin{tabular}{|c|c|c|c|c|c|c|}
\hline \multirow[b]{2}{*}{ No. } & \multirow[b]{2}{*}{ Year } & \multicolumn{4}{|c|}{ Type } & \multirow[b]{2}{*}{ Total $\left(\mathbf{T} / \mathbf{M}^{3}\right)$} \\
\hline & & $\operatorname{Import}\left(\mathbf{T} / \mathbf{M}^{3}\right)$ & $\operatorname{Export}\left(\mathbf{T} / \mathbf{M}^{3}\right)$ & $\begin{array}{c}\text { Domestic } \\
\text { Unloading } \\
\left(\mathbf{T} / \mathbf{M}^{3}\right)\end{array}$ & $\begin{array}{c}\text { Load } \\
\text { Domestically } \\
\left(\mathbf{T} / \mathbf{M}^{3}\right)\end{array}$ & \\
\hline 1. & 2011 & 1.159 .663 & 745.118 & 7.517 .004 & 4.455 .572 & 13.877 .357 \\
\hline 2. & 2012 & 1.514 .450 & 1.829 .361 & 6.644 .178 & 4.129 .887 & 14.117 .876 \\
\hline 3. & 2013 & 1.070 .417 & 554.474 & 6.123 .037 & 5.073 .912 & 12.821 .840 \\
\hline 4. & 2014 & 1.378 .586 & 549.727 & 5.291 .747 & 5.609 .244 & 12.829 .304 \\
\hline 5. & 2015 & 1.499 .141 & 661.580 & 5.300 .722 & 4.882 .898 & 12.344 .341 \\
\hline 6. & 2016 & 1.376 .512 & 397.342 & 4.675 .024 & 5.195 .027 & 11.643 .905 \\
\hline 7. & 2017 & 1.478 .955 & 407.929 & 4.396 .082 & 5.844 .425 & 12.127 .391 \\
\hline 8. & 2018 & 1.707 .681 & 396.521 & 7.197 .656 & 6.472 .460 & 15.774 .318 \\
\hline 9. & 2019 & 1.481 .578 & 467.066 & 9.565 .958 & 6.911 .562 & 18.426 .164 \\
\hline
\end{tabular}

Source: Makassar Main Port Authority

3. Effect of Makassar Port in Supporting the Development of Makassar City

1. Results of Correlation Analysis

In the correlation method, the correlation coefficient value will be obtained in the range of 0 1 , where if it is 0 indicates no correlation and if it is
1 it indicates perfect correlation. Correlation can be positive or negative if it is positive it indicates the unidirectional value and if it is negative it indicates that the relationship is not unidirectional. The results of correlation analysis using MS Excel software obtained output as in Table 3.

Table 3. GRDP Correlation Statistics Test Results and Goods Traffic Flow

\begin{tabular}{lrrrrrr}
\hline & Export & Import & $\begin{array}{c}\text { Domestic } \\
\text { UnloadingDomestically }\end{array}$ & Total & GRDP \\
\hline Export & 1 & & & & & \\
Import & 0,0568 & 1 & & & & \\
Domestic Unloading & 0,1140 & 0,0627 & 1 & & \\
Load Domestically & $-0,6657$ & 0,4474 & 0,3505 & 1 & \\
Total & 0,0210 & 0,3388 & 0,9396 & 0,5899 & 1 \\
GRDP & $-0,5653$ & 0,6332 & 0,2492 & 0,9147 & 0,5145 & 1 \\
\hline
\end{tabular}

Source: Analysis Results, 2020

Based In Table 3 it can be seen that the highest correlation value is found in the domestic www.psychologyandeducation.net 
load of 0.9147 , which means that the correlation is very strong, imports of 0.6332 , and total flow goods traffic of 0.5145 which shows a strong correlation. The correlation is very strong and strong or significant, which means that the increase in the flow of total, import, and domestic cargo traffic will also increase the GRDP of Makassar City. The very weak correlation is shown in the domestic unloading variable of 0.2492 . Negative correlation (not unidirectional) is shown in the export variable. The negative correlation coefficient (not unidirectional) means that if the export variable is high, the GRDP variable will below. From the results of the correlation analysis, it shows that three variables are strongly correlated, one variable is very weakly correlated and one variable is not unidirectional, so it can be said that there is a relationship between Makassar Port and the development of Makassar City.

2. Results of Simple Linear Regression Analysis

The variables used in the simple linear regression analysis are domestic loading because this variable has a very strong correlation to the total GRDP. In the regression method, an value will be generated $R$-square which is a reference to determine whether the $\mathrm{X}$ variable or in this case the Makassar Port (domestic load) affects the development of Makassar City (Makassar City GRDP) which is the $\mathrm{Y}$ variable. If the $P$-value approaching zero, the effect of Makassar Port on the development of Makassar City reaches a significant value. The results of simple linear regression analysis using software Ms. Excel, the output is obtained as shown in Table 4 and Table 5.

Table 4. Summary Output Regression GRDP and Fit Domestic Regression Statistics

\begin{tabular}{lr}
\hline Multiple R & 0,91471515 \\
R Square & 0,8367038 \\
Adjusted R Square & 0,81337577 \\
Standard Error & 16381099,6 \\
Observations & 9
\end{tabular}

Source: Analysis Results, 2020

Table 5 ANOVA GRDP Regression and Domestic Loading

\begin{tabular}{lrrrrc}
\hline & & & & & \multicolumn{2}{c}{ Significance } \\
& $d f$ & & \multicolumn{1}{c}{ SS } & \multicolumn{1}{c}{$M$} & \multicolumn{1}{c}{$F$} \\
\hline Regression & 1 & $9,62454 \mathrm{E}+15$ & $9,62454 \mathrm{E}+15$ & 35,866888 & 0,0005483 \\
Residual & 7 & $1,87838 \mathrm{E}+15$ & $2,6834 \mathrm{E}+14$ & & \\
Total & 8 & $1,15029 \mathrm{E}+16$ & & & \\
\hline
\end{tabular}

\begin{tabular}{|c|c|c|c|c|c|c|c|}
\hline \multirow{2}{*}{ Coefficients } & \multicolumn{2}{|l|}{ Standard } & \multirow[b]{2}{*}{ P-value } & \multirow[b]{2}{*}{ Lower $95 \%$} & \multicolumn{3}{|c|}{ Lower } \\
\hline & Error & $t$ Stat & & & Upper $95 \%$ & $95,0 \%$ & Upper $95,0 \%$ \\
\hline & & & & & & & \\
\hline 38,1 & 6,37774 & 98889706 & 0,00 & 23,114670 & 53,276 & 11467098 & 53,27659003 \\
\hline
\end{tabular}


Source: Analysis Results, 2020

Based on simple linear regression models as follows:

$$
Y=-88651116,03+38,1956305 X
$$

Effect of Makassar port (unloading in the country) for the development of Makassar (GDP Makassar City) during the period of the last nine years, the value of $R$ square of 0.8367038 which means that the influence of the domestic load variable on the GRDP variable is $83 \%$, while the rest is influenced by other variables outside the research. The $P$-value of 0.0005483 is close to zero so that the effect is significant. In using this model, it can be said that $1 \mathrm{Ton} / \mathrm{M}^{3}$ of domestic load affects the 38.1956305 GRDP value of Makassar City. The effect of domestic loading on GDP in various sectors can be seen in Table 6 .

Table 6. Domestic Load Regression Statistics Test Results against GRDP

\begin{tabular}{|c|c|c|c|c|}
\hline \multirow{2}{*}{ No. } & \multirow{2}{*}{ Industry } & \multicolumn{3}{|c|}{ Analisis Results } \\
\hline & & R Square & P-value & Model \\
\hline 1. & Agriculture, Forestry and Fishing & 0,7425 & 0,0028 & $\begin{array}{l}f x(y)=-178878,7983+ \\
0,1535 X\end{array}$ \\
\hline 2. & Mining and Quarrying & 0,7695 & 0,0019 & $\begin{array}{l}f x(y)=3554,0763- \\
0,0004 X\end{array}$ \\
\hline 3. & Manufacturing & 0,7802 & 0,0016 & $\begin{array}{l}f x(y)=-11308187,3898+ \\
6,3732 x\end{array}$ \\
\hline 4. & Electricity and Gas & 0,8560 & 0,0003 & $\begin{array}{l}f x(y)=-17507,72272+ \\
0,0102 X\end{array}$ \\
\hline 5. & $\begin{array}{l}\text { Water Supply, Sewerage, Waste Management } \\
\text { and Remediation Activities }\end{array}$ & 0,8449 & 0,0005 & $\begin{array}{l}f x(y)=32427,9355+ \\
0,0412 x\end{array}$ \\
\hline 6. & Construction & 0,8469 & 0,0004 & $\begin{array}{l}f x(y)=-21303416,2919+ \\
7,6744 x\end{array}$ \\
\hline 7. & $\begin{array}{l}\text { Wholesale and Retail Trade, Repair of Motor } \\
\text { Vehicles and Motorcycles }\end{array}$ & 0,8442 & 0,0005 & $\begin{array}{l}f x(y)=-20822318,4994+ \\
8,0429 x\end{array}$ \\
\hline 8. & Transportation and Storage & 0,8365 & 0,0006 & $\begin{array}{l}f x(y)=-2316953,1098+ \\
0,9897 X\end{array}$ \\
\hline 9. & Accomodation and Food Service Activities & 0,8445 & 0,0005 & $\begin{array}{l}f x(y)=-1767858,7614+ \\
0,8292 X\end{array}$ \\
\hline 10. & Information and Communication & 0,8598 & 0,0003 & $\begin{array}{l}f x(y)=-6577452,9419+ \\
3,2458 X\end{array}$ \\
\hline 11. & Finansial and Insurance Activities & 0,8078 & 0,0010 & $\begin{array}{l}f x(y)=-5416441,6582+ \\
2,3081 X\end{array}$ \\
\hline 12. & Real Estate Activities & 0,7541 & 0,0024 & $\begin{array}{l}f x(y)=-2376801,2222+ \\
1,2939 x\end{array}$ \\
\hline 13. & Jasa Perusahaan & 0,8481 & 0,0004 & $\begin{array}{l}f x(y)=-1176573,1077+ \\
0,4741 X\end{array}$ \\
\hline 14. & $\begin{array}{l}\text { Public Administration and defence, Compulsory } \\
\text { Social Security }\end{array}$ & у 0,7894 & 0,0014 & $\begin{array}{l}f x(y)=-2190696,2934+ \\
1,1638 x\end{array}$ \\
\hline
\end{tabular}




$\begin{array}{lrrr}\text { 15. Education } & 0,8542 & 0,0004 & \mathrm{fx}(\mathrm{y})=-7066461,5504+ \\ & & 3,2789 \mathrm{X}\end{array}$

Source: Analysis Results, 2020

Based In Table 6, it can be seen that the average $R$-square value is greater than 0.7 , which means that the effect of domestic loading variables on the GRDP variable is more than $70 \%$., while the rest is influenced by other variables outside the research. The $P$-value is average close to zero, so it can be said that the effect is significant. Based on these results it can be concluded that the Makassar Port has a significant effect on the development of Makassar City.
3. Makassar Port Operational Performance

Based on the results of the Makassar Port performance analysis, data shows that during the last five (5) years, most of the Makassar Port operational performance appraisals category performed well, although there were still some criteria that performed poorly and quite well. The results of the analysis of the operational performance of the Makassar port can be seen in Table 7.

Table 7. Makassar Port Operational Performance

Operational Performance Standards

Indicators

Standard

Value

WT $\quad 1 \quad$ hours

AT $\quad 1,25 \quad$ hours

$\mathrm{ET} / \mathrm{BT}$

GC

25

$\mathrm{BC}$

30

$\mathrm{T} / \mathrm{G} / \mathrm{H}$

UN

Unit

$\mathrm{T} / \mathrm{G} / \mathrm{H}$

$\mathrm{T} / \mathrm{G} / \mathrm{H}$
Description

T. Konv TPM MNP

Domestic $\quad 0,00 \quad 0,00 \quad 0,00$

Overseas

Domestic

Overseas

Domestic

Overseas

Domestic

Overseas

Domestic

Overseas

Domestic
Performance

Performance

Assesment

Good

Good

Good

Under

Performing

Good

Good

Good

Good

Good

Good

Overseas 
Operational Performance Standards

Indicators

Standard

Value

CC

CK

Productivity

25

38

30

45

70

65

70

90

Equipment

Readiness
Unit

Description

Domestic

$\mathrm{T} / \mathrm{H}$

$\mathrm{T} / \mathrm{H}$

$\mathrm{B} / \mathrm{C} / \mathrm{H}$

$\mathrm{B} / \mathrm{S} / \mathrm{H}$

Minutes

Minutes

$\%$

$\%$

$\%$

$\%$

\section{Performance}

T. Konv TPM MNP

Performance

Assesment

Under

Performing

Under

Performing

Domestic 114,60 Good

Overseas $\quad 214,33$

Good

Good

Good

Good

Good

36,06

2,76

4,43

$54,87 \quad 4,43$

Good

$89 \quad 89 \quad 89$

Quite Good

performance

Source: Analysis Results, 2020

Waiting Time, Effective Time/Berthing Time, Approach Time of domestic ships, the productivity of loading and unloading of non-container goods (General Cargo and Bag Cargo), the level of use of docks, warehouses, storage fields, and The productivity of loading and unloading of container goods are performing well or by the operational performance standards set by the port operator.

Approach Time of foreign ships has underperformed during the last five (5) years if averaged far above the standard performance set at 1.25 hours. The productivity of loading and unloading of liquid bulk non-container goods also has poor performance because the value is far below the performance standard set at $150 \mathrm{~T} / \mathrm{H}$. This is because the ship's blower for unloading only uses 1 unit and is slow to heat with a capacity of
$100 \mathrm{~T} / \mathrm{H}$ and the distance between the pipe and the stacking plant is quite far. The readiness of the equipment performs quite well because it is only around $89 \%$ of the performance standard set at 90\%. Equipment readiness that has fairly good performance is ground equipment. This is due to limited loading and unloading of production equipment and equipment maintenance.

4. Strategies for Increasing the Role of Ports in Supporting the Development of Makassar City

The strategy to increase the role of ports is carried out by improving port performance. Improving port performance is done by first identifying what are driving factors and constraining factors. The driving factor for 
increased performance is obtained from the port performance indicators that get good performance, while the inhibiting factor is obtained from the performance indicators with fairly good and poor performance. The driving factors and the inhibiting factors are then given weighted scores by the representatives of policymakers at the Makassar
Port. The weighting aims to determine the priority of planning that will be carried out in improving performance. Based on the planning priorities that have been made then formulate strategies that can be utilized in improving the performance of the Makassar Port as presented in Table 8.

Table 8. Port Role Improvement Strategy Through Improved Port Performance

\section{Driving Factors}

Strategy

D1 Productivity of container loading and Makassar New Port Container Terminal unloading goods and Receiving / Delivery Development perform well

D2 The productivity of loading and unloading of Increasing the productivity of loading and non-goods General Cargo, Bag Cargo, andunloading workers and the capacity of Dry Bulk performs well

loading and unloading equipment

D3 The level of use of docks, warehouses, and Increase the use of docks, warehouses, and piling yards performs well stockpiles to cope with the increase in the flow of goods

D4 Waiting Time and ET:BT ships perform well Optimizing the use of the Inaportnet application that facilitates the service of ships and goods. ship handling,

Inhibiting Factors

I1 Approach time for foreign ships under Dredging of port ponds especially for performing

I2 Equipment readiness is a quite performance

\section{Strategy}

foreign ships that have large drafts 
1. Makassar Port has a significant effect in supporting the development of Makassar City and Makassar Port's performance during Overall, the last five (5) years have performed well.

2. The strategic priorities for increasing the role of Makassar Port in supporting the development of Makassar City are the development of the Makassar New Port (MNP) terminal and dredging the port pool.

\section{ACKNOWLEDGMENT}

This work was made by Rini, Budimawan, and GandingSitepu from Hasanuddin University.

\section{REFERENCES}

[1] Adisasmita, R. (2018). Pembangunan EkonomiPerkotaan. GrahaIlmu.

[2] Adisasmita, S. A. (2011). TransportasidanPengembangan Wilayah (pertama). Yogyakarta: GrahaIlmu.

[3] Dewi, E. P., Purwanto, M. Y. J., \&Sapei, A. (2014). SkenarioPengembangan Wilayah Berbasis Daerah Irigasi (StudiKasus: di CiheaKabupatenCianjur). 9(2), 86-95.

[4] Mandasari, M., Kusumastanto, T., \&Mulyati, H. (2017). AnalisisKebijakanEkonomiPengembanganP elabuhan di Provinsi Aceh. JurnalEkonomi Dan Pembangunan Indonesia, 18(1), 92 108. https://doi.org/10.21002/jepi.v18i1.722

[5] Oblak, R., Bistricic, A., \&Jugovic, A. (2013). Public private partnershipmanagement model of Croatian seaports. Management, 18, 79-102.

[6] Putra, A. A., \&Djalante, S. (2016). PengembanganInfrastrukturPelabuhanDala mMendukung Pembangunan Berkelanjutan. JurnalIlmiah Media Engineering Vol.6 No.1, 433-443.
[7] Syam, N. A. (2013). Tata RuangWIlayah Dan Kota (Cetakan 1). Makassar: Alauddin University Press.

[8] Triatmodjo, B. (2010).

PerencanaanPelabuhan. Yogyakarta: Beta Offset Yogyakarta.

[9] Yudhistira, M. H., \&Sofiyandi, Y. (2018). Seaport status, port access, and regional economic development in Indonesia. Maritime Economics and Logistics, 20(4), 549-568. https://doi.org/10.1057/s41278017-0089-1

[10] Yusuf, A. M. (2016). MetodePenelitianKuantitatif, Kualitatif\&PenelitianGabungan. Prenada Media. 